\title{
Ground-Water Modeling of the Death Valley Region, Nevada and California
}

\section{Why is Ground Water Important in the Death Valley Region?}

Water is a precious commodity. especially in the arid southwest region of the United States, where there is a limited supply of both surface water and ground water. Ground water has a variety of uses (such as agricultural, commercial. and domestic) in the Death Valley regional ground-water flow system (DVRFS) of southern Nevada and eastern California. The DVRFS, an area of about 100,000 square kilometers, contains very complex geology and hydrology. Using a computer model to represent this complex system, the U.S. Geological Survey (USGS) simulated ground-water flow in the Death Valley region (fig. 1) for use with U.S. Department of Energy (DOE) projects in southem Nevada (Belcher, 2004). The model was created to help address contaminant cleanup activities associated with the underground nuclear testing conducted from 1951 to 1992 at the Nevada Test Site and to support the licensing process for the Nation's proposed geologic repository for high-level nuclear waste at Yucca Mountain, Nevada.

\section{Geospatial data sets} are available through an online interactive map viewer and ean be accessed at httpt//rockyitr.cr.usgs.gov/DVAFSIntro or by the hyperlink on figure 3 .

\section{The MODFLOW-2000 Death} Valley regional ground-water flow model archive can be accessed at fipy/ftpregmod.wr.usgs. gov/DVRFS_2004_SIR-5205

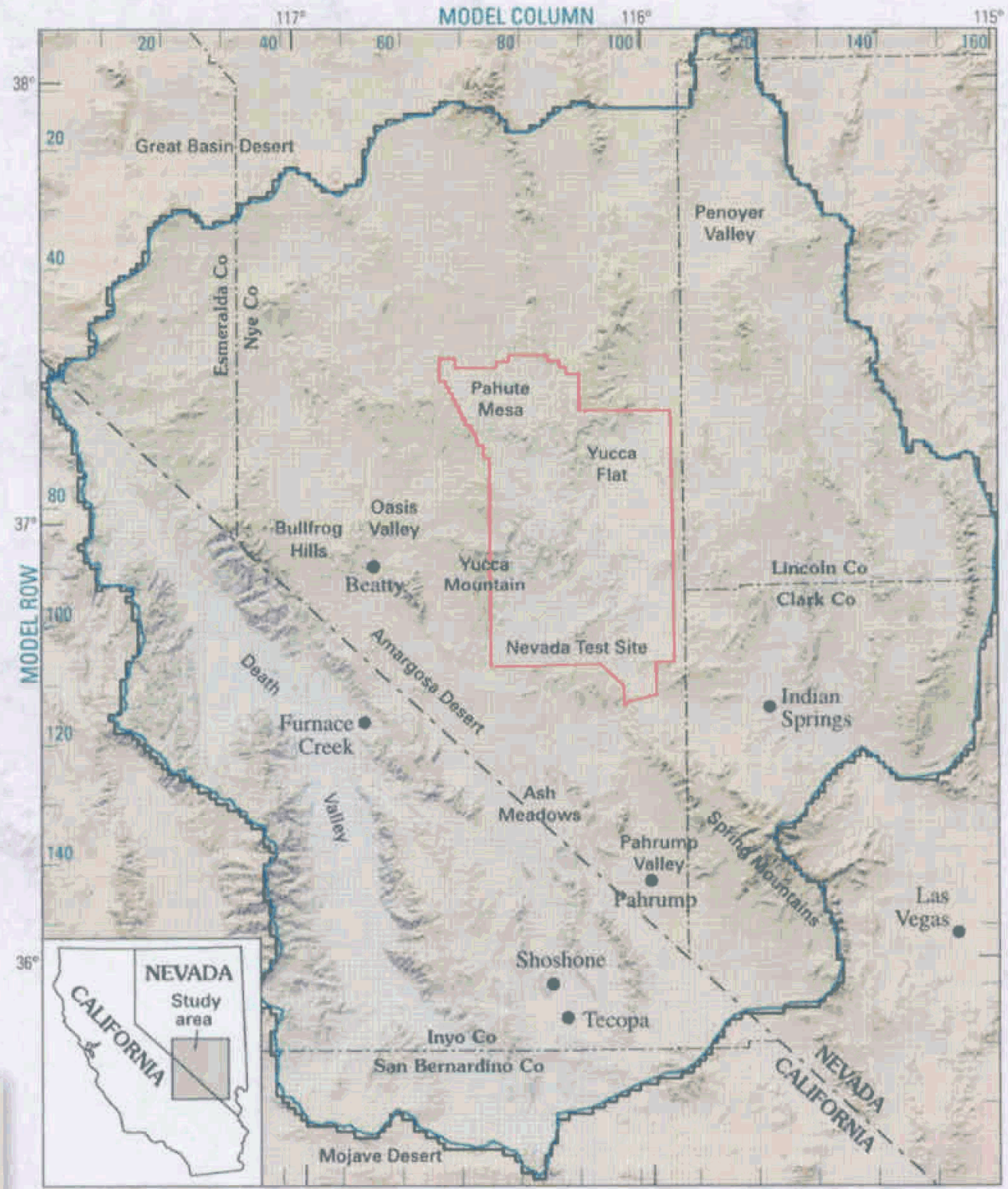

Shaded-ruief base from 1.250,000-scale Digutal Bevation Model sun illumination from northwest at 30 degrees above horizon

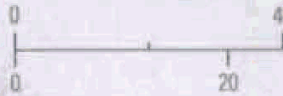

80 KLLOMETEAS

$$
\begin{array}{|c|c|}
\hline \text { Active cells } & 0 \\
\text { Inactive cells } & \text { NXIANATION } \\
\hline \text { Nevada Test Site boundary } & \text { Death Valley regional ground-water } \\
\text { flow system model boundary } & \text { Death Valley regional ground-water } \\
& \text { flow system model grid boundary }
\end{array}
$$

Figure 1. Map showing the location and computer model grid of the Death Valley regional ground-water flow system, Nevada and California. 


\section{Ground-Water Flow}

Ground-water flow in the Death Valley region is complex. with two main flow systems-relatively shallow local and intermediate systems where water flow is restricted to individual basins and a deeper, regional tlow system, where water flows from one basin to another (fig. 2). Ground water flows from recharge areas in the mountains of central and southern Nevada to discharge areas of wet playas and springs that are south and west of the Nevada Test Site and in Death Valley, California (fig. 1). The concept of how water flows in the DVRFS is based on decades of studying geology. water levels, water chemistry, and water temperatures (D'Agnese and others, 1997, p. 5). Regional groundwater flow is mainly in the thick Palcozoic carbonate rocks through faults and fractures.

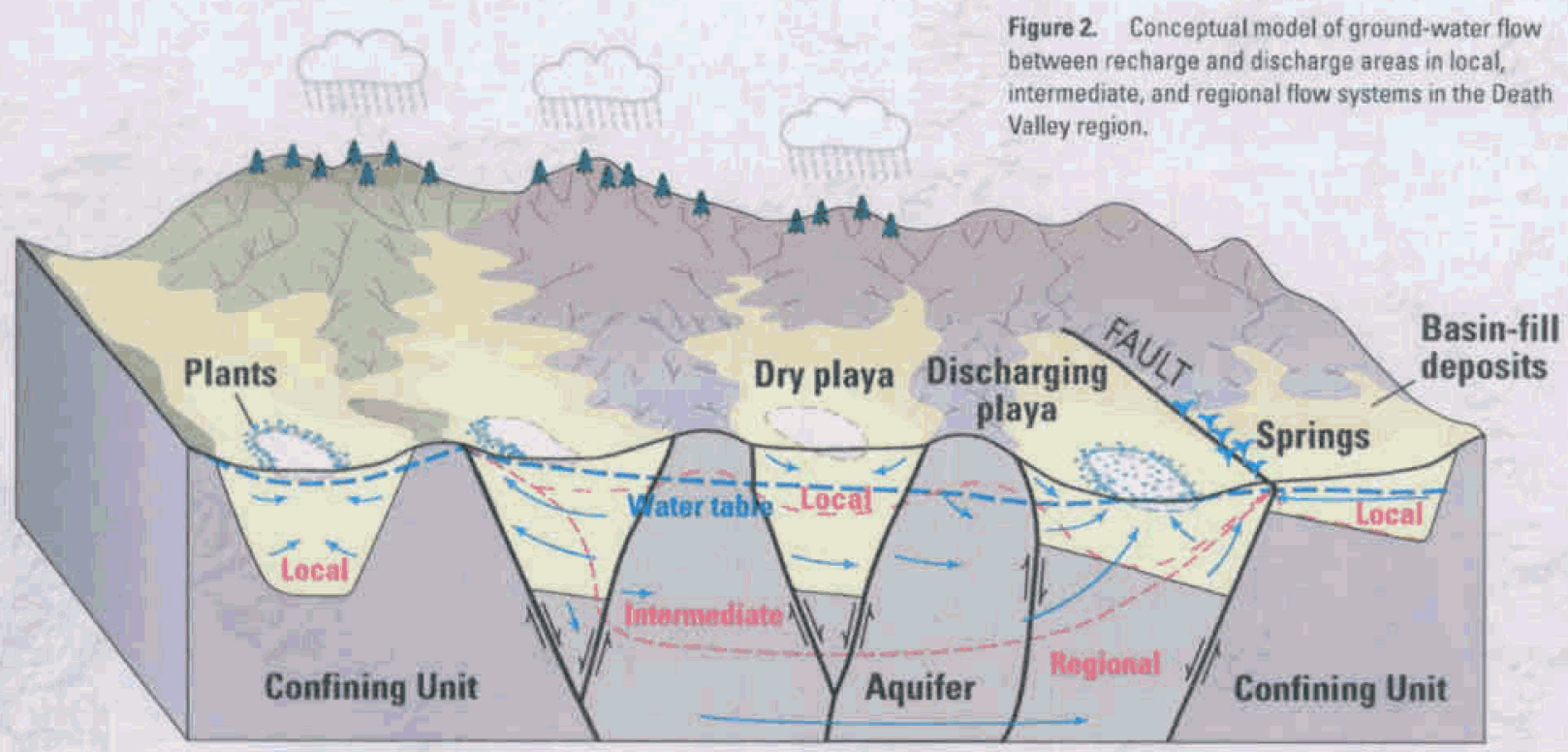

\section{Hydrogeologic Units}

Geologic rock units in the DVRFS were combined into hydrogeologie units - units that have the same or similar properties of groundwater flow. The ability of rocks and sediments to transmit water in the DVRFS depends on their physical properties, which reflect how they were deposited and their geologic history. These physical properties can include the grain size and amount of cementation of the sediment making up a rock or deposit, the amount of welding in volcanic tuffs, and the chemical alteration of rock from ground-water flow. For instance, the larger grain size of sand (compared to silt or mud) in a rock or deposit makes it easier for water to flow through the pore spaces between the grains of the rock or deposit, unless cementation fills these pore spaces.

The hydrogeologic units represent the principal aquifers (waterbearing units) and confining units (water-restricting units) of the region. The hydrogeologic units are made up of (generally youngest to oldest):

- Cenozoic basio-fill and piaya deposits (local aquifers and confining units, depending on the grain size of the sediment and the amount of cementation).

- Cenozoic voleanic rocks (aquifers and confining units, depending on their physical properties and rock types; important focal and intermediate aquifers in the vicinity of Oasis Valley. Pahute Mesa, and Yucca Mountain),

- Cenozoic and Mesozoic intrusive igneous rocks (local confining units).
- Mesozoic sedimentary and volcanic rocks (aquifers and confining units, depending on their physieal properties and rock types).

- Paleozoic carbonate rocks (main regional aquifet)

- Paleozoic to Late Proterozoic sedimentary rocks (main regional confining unit), and

- Proterozoic igncous and metamorphic rocks (regional confining unit. generally forming the bottom of the flow system).

Ground-water flow also is affected by geologic structures in the rocks. Faults and fractures can allow rock to transmit water better by increasing the amount of openings. Faults can restrict ground-water flow when fault movement forms ground-up rock in the fault, known as gouge. Faults also can change directions of ground-water flow by placing aquifers next to confining units.

\section{Three-Dimensional Hydrogeologic Framework Model}

To develop a ground-water flow model of the DVRFS, it is necessary to define the 3-D geometry of the hydrogeologic units by using surface and subsurface geologic information, such as digital elevation models, geologic maps, borehole information, geologic and hydrogeologic cross sections, and other 3-D computer models. The geometries of 27 hydrogeologic units were used to construct a digital hydrogeologic framework model, which was used as input for the ground-water flow model. The areas of Pahute Mesa and Yucea Mountain contain more detail because these areas are of interest for local-scale modeling 


\section{Hydrologic Components for Model Development}

To simulate ground-water flow, the hydrologic components of the system need to be defined. These inelude the amount and locations of water entering (recharge) and exiting (discharge) the system, the ability of each hydrogeologic unit to transmit and store water, changes in this ability with depth, and the location and depth to ground water. A statistical "weight" was applied to the water levels and flows to account for the level of confidence in the accuracy of the measurements, Ground water enters the DVRFS by recharge from precipitation (mostly in the mountains of central and southern Nevada) and by flow across the system boundary from some adjacent ground-water basins. Ground water exits the DVRFS (1) naturally, by spring flow and evapotranspiration (evaporation of ground water and transpiration from plants) in Ash Meadows and Oasis Valley, south and west of the Nevada Test Site and in Death Valley, California, and by flow across the system boundary to some adjacent ground-water basins, and (2) since 1913, by pumping for agricultural, commercial, and domestic use, mostly in Pahrump Valley, Amargosa Desert, and Penoyer Valley (fig, 1). A series of studies was completed to measure or define these values as inputs for the model by compiling previously existing information, by acquiring additional information when needed, and by refining earlier ideas on ground-water flow in the DVRFS to reflect the current understanding.

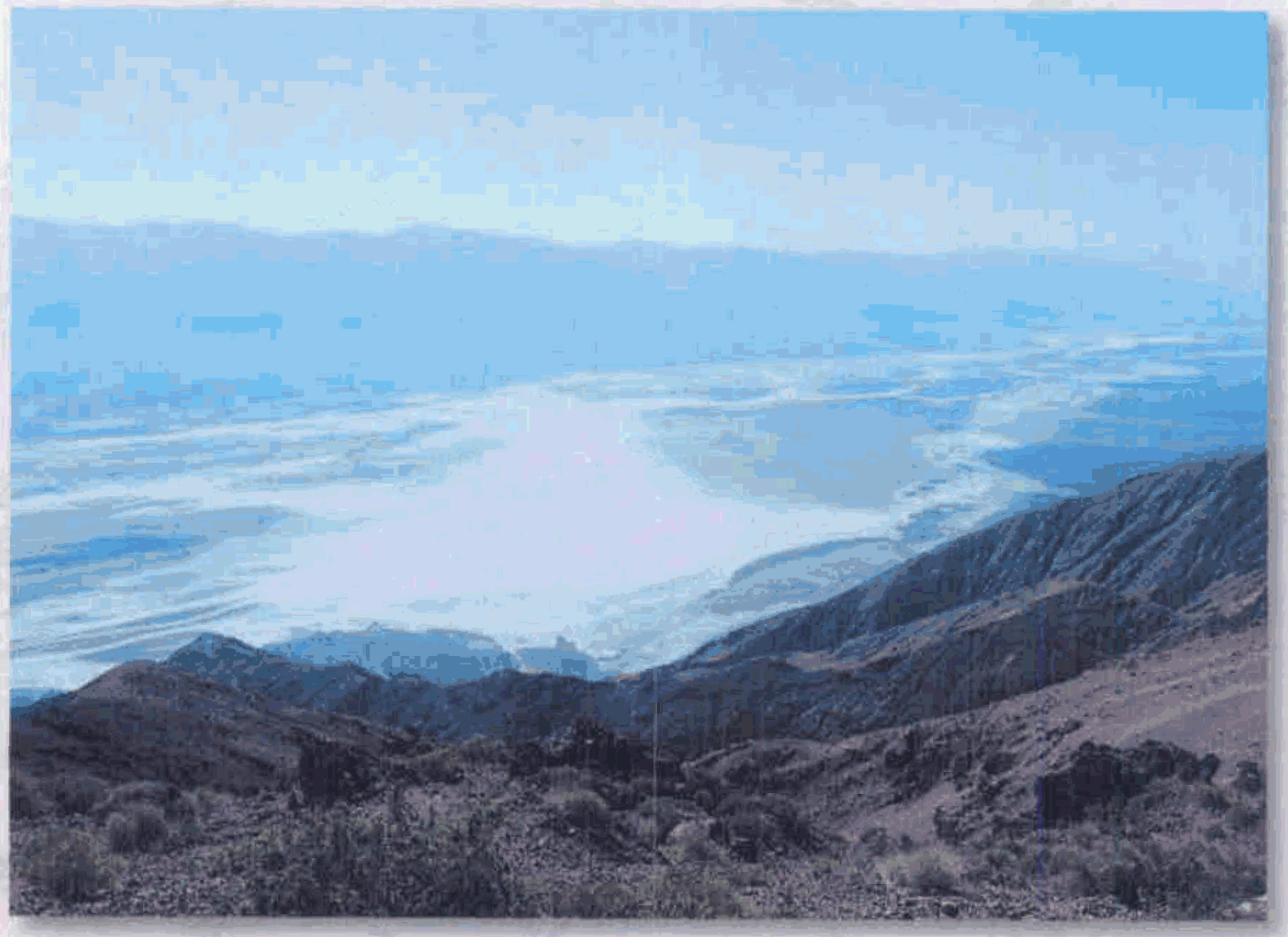

Death Valley, California, from Dante's Viaw looking northwest. Phatograph by WR. Belcher.

\section{Ground-Water Flow Model, Calibration, and Results}

Model

Ground-water flow, like many natural processes, can be described using mathematical equations, Ground-water flow in the DVRFS was simulated using the USGS computer model, MODFLOW-2000 (Harbaugh and others, 2000), which uses a numerical method called "finite differences" to solve these flow equations. The DVRFS model was divided into a grid of 16 layers with 194 rows and 160 columns of cells $1,500 \mathrm{~m}$ on a side (fig. 1 ).

\section{Calibration}

To test the model input values for all the hydrogeologic unit parameters and for recharge and discharge amounts and locations, model simulations were repeated and input parameters adjusted until the simulated water-level and spring-flow values matched the measured water-level and flow values. The model iuputs defining the ability of hydrogeologic units to transmit and store water were changed after cach run until a match was obtained. This process is called "calibration" of the model. Measurements of steady-state ground-water levels, the amount of spring flow, and the amount of evapotranspiration were used to calibrate the model for initial steady-state conditions (before pumping began in the region in 1913). The model then was calibrated for transient conditions using transient water levels, the amount of spring flow, the amount of evapotranspiration, and the volume of pumping from 1913 through 1998. Calibration matches commonly are expressed as the differences, called residuals, between measured and simulated values of water levels and of flows. Weighted residuals are the differences between the measured and simulated values multiplied by the weights, Weighted residuals are a better indication of the calibration of the model than residuals because they take into account the accuracy and the importance of the measured values. The statistical meaning of the weighted residual numbers is complicated and they are unitless. The weighted residual value of 5 is arbitrary for the simulation results in figure 3 . 


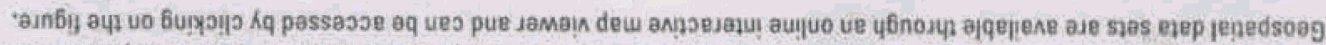

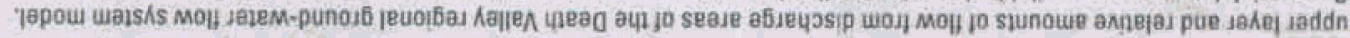

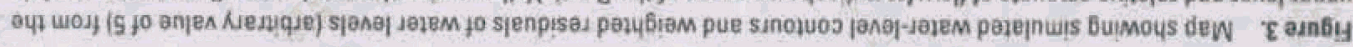

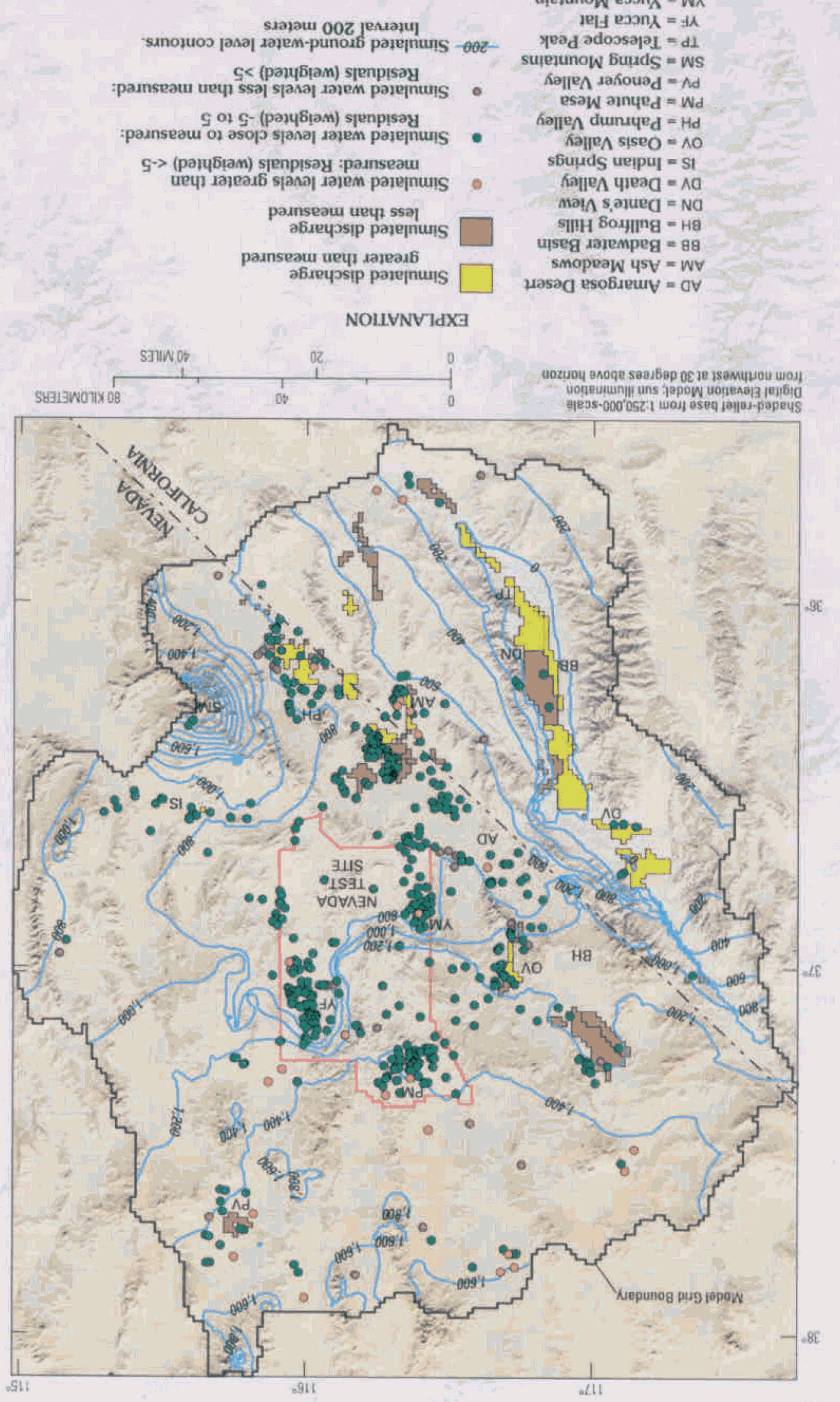




\section{Results}

The model simulations of ground-water flow in the DVRFS match the observed ground-water flow patterns, generally from north to south, originating from recharge of precipitation in the mountains in central and southern Nevada and discharging at regional discharge areas in Ash Meadows, Oasis Valley, and Death Valley (fig. 3). The simulated ground-water levels generally match measured water levels (fig. 3, green data points) except in areas where the water leveis change rapidly over a short distance (steep hydraulic gradient). such as Indian Springs, western Yucea Flat, and the southern part of the Bullirog Hills. The simulated water levels generally match the decline of water levels over time in the Pahrump Valley, Amargosa Desert, and Penoyer Valley areas and is, thought to be related to pumping. The model adequately simulated the observed decline of spring Now because of pumping in Pahrump Valley during the last century. In the final calibration, the simulated values that define the ability of a hydrogeologic unit to transmit and store water match the range of values measured in the field.

\section{Cited References}

Belcher, W.R., ed., 2004, Death Valley regional ground-water flow system, Nevada and California- Hydrogeologic framework and transient ground-water flow model: U.S. Geological Survey Seientific Investigations Report $2004-5205,408$ p. Available online at hitp://pubs.waterasgs, gow/sir2004-5205/

D'Agnese, F.A., Faunt, C.C., Turner, A.K., and Hill, M.C., 1997. Hydrogeologic evaluation and numerical simulation of the Death Valley regional ground-water flow system, Nevada and California: U.S. Geological Survey Water-Resources Investigations Report $96-4300,124 \mathrm{p}$.

Harbaugh, J.W., Banta, E.R., Hill, M.C., and McDonald, M.G., 2000, MODFLOW-2000, The U.S. Geological Survey's modular groundwater flow model- User guide to modularization concepts and the ground-water flow process: U.S. Geological Survey Open-File Repont 00-92, $121 \mathrm{p}$.
The model can be used as a tool for resource managers and decision makers to simulate the future effects of different amounts or locations of pumping on ground-water levels, spring flows, and ground-water flow paths in the DVRFS. Water availability. water-dependent eco-systems, and contaminant migration may be affected by pumping The model can be a valuable tool for managing the scarce water resources in the region and for addressing complex socioeconomic and political issues about water uses in the region. The DVRFS model represents a large and complex ground-water flow system with a greater degree of detail and accuracy than previous studies.
By

W.R. Beleher, C.C. Faunt, D.S. Sweetkind, J.B. Blainey, C.A. San Juan, R.J. Laczniak, and M.C. Hill

Layout design and modification of graphics by Mari Kauffmann (Contractor, ATA Services) Original graphics by N.A. Damar, R.R. Contreras, and L.L. Rogers.

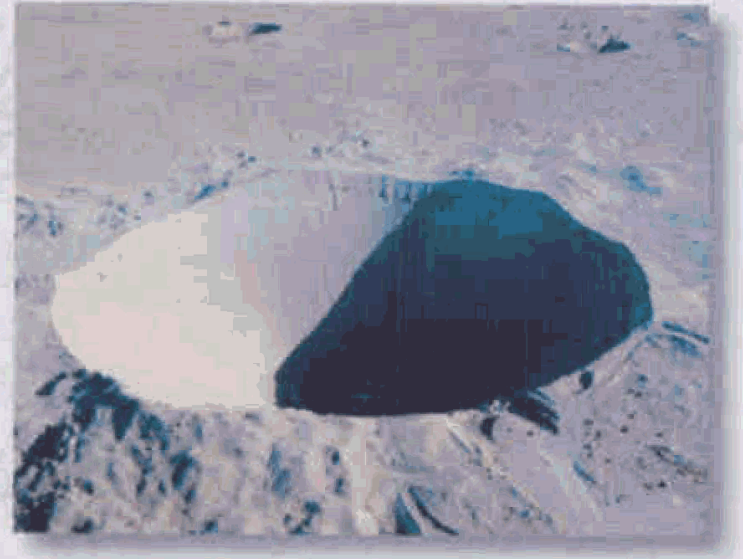

Nuclear testing at the Nevada Test Site in Nye County Nevada. Photagraph from U.S. Department of Energy.

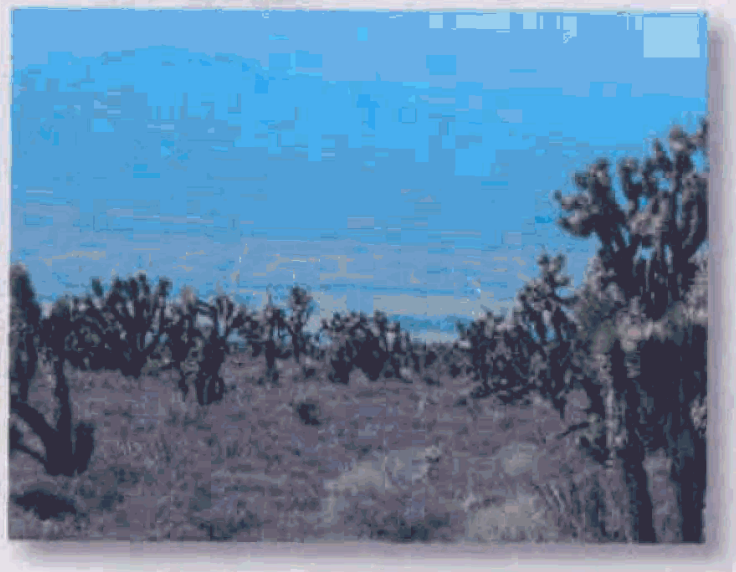

Urbanization in Pahrump Valley, Nye County, Nevada. Photograph by WR. Eelcher.

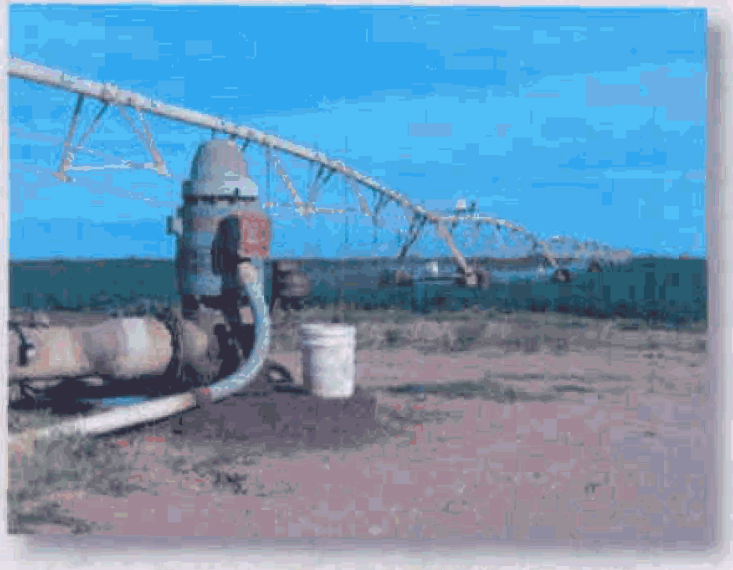

Agricultural irrigation in Amargosa Desert, Nye County, Nevada. Photograph by A.J. Laczniak.

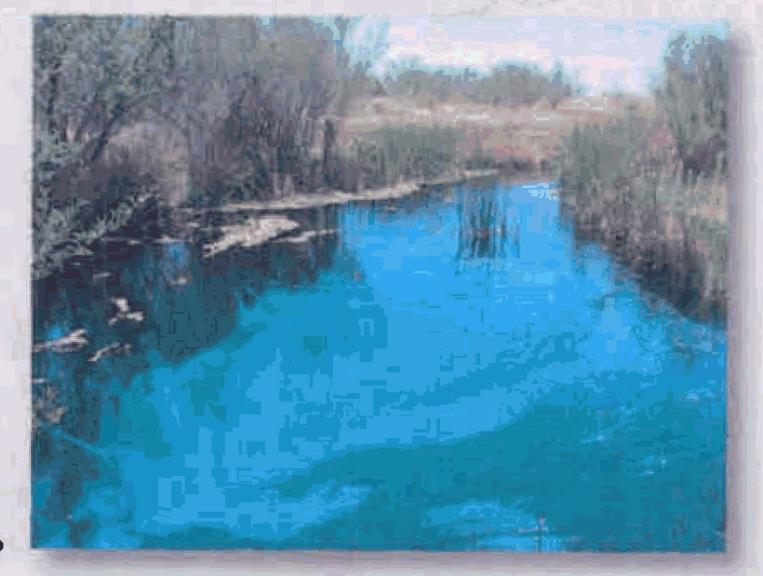

Crystal Pool spring, Ash Meadows National Wildlife Refuge, Nye County, Nevada, Photograph by R.J. Lacrniak. 


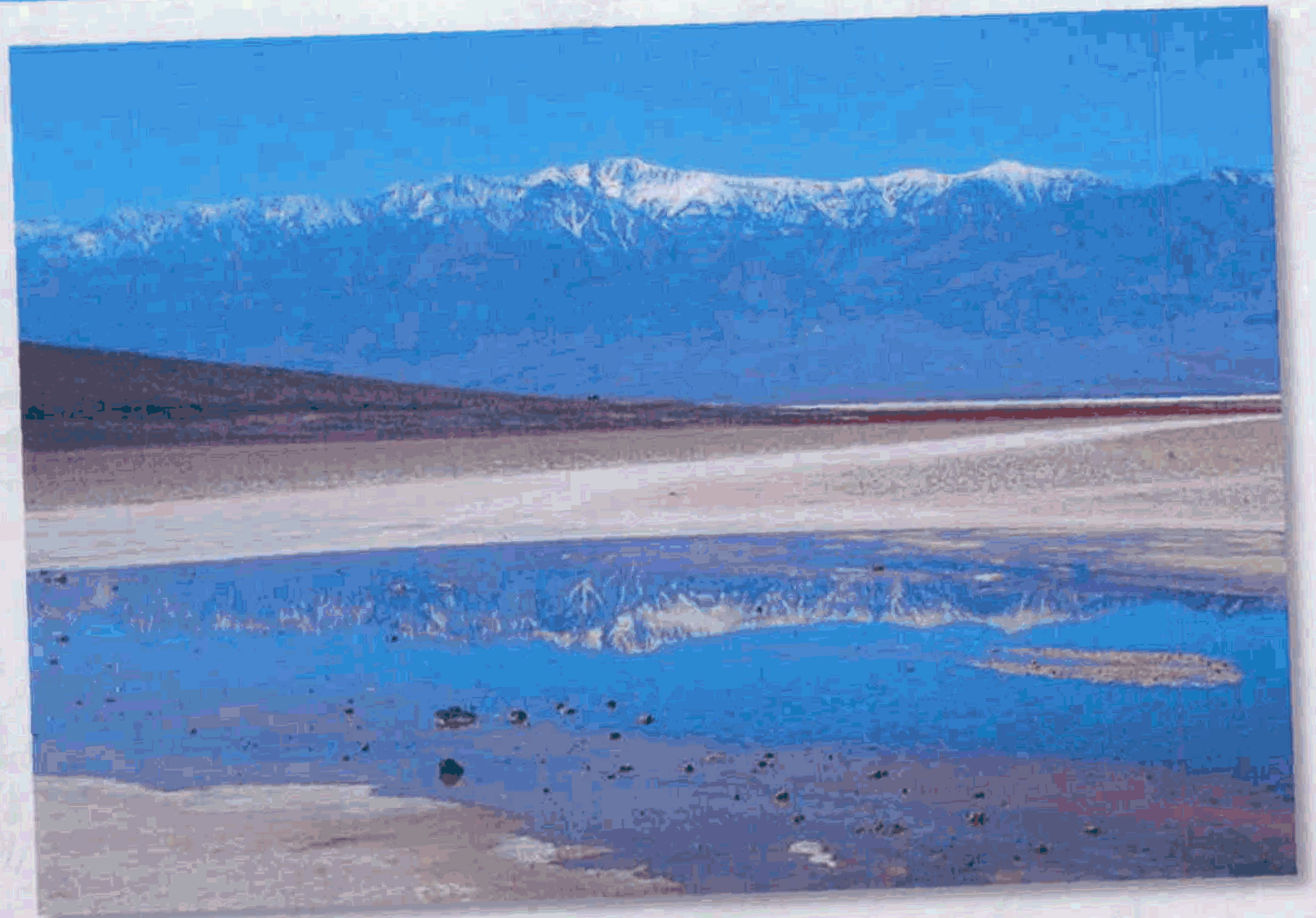

Telescope Peak from Badwater Basin, Death Valley, California, looking west. Photograph by R.J. Laczniak.

\section{Cooperating Organizations}

U.S. Department of Energy, National Nuclear Security Administration, Nevada Site Operations, under Interagency Agreement DE-AI52-01NVI3944

U.S. Department of Energy, Office of Civilian Radioactive Waste Management, under Interagency Agreement DE-A128-02RW 12167 National Park Service

U.S. Fish and Wildlife Service

Bureau of Land Management

U,S. Air Force

Nye County, Nevada

Inyo County, California

\section{For More Information Contact:}

U.S. Geological Survey

Nevada Water Science Center

160 North Stephanie Street

Henderson, NV 89074

Telephone: (702) 564-4500

World Wide Web:

hitp:ifregmod.wriasgs.gow

hitpillpubs water usgs gow/sir2004-5205/

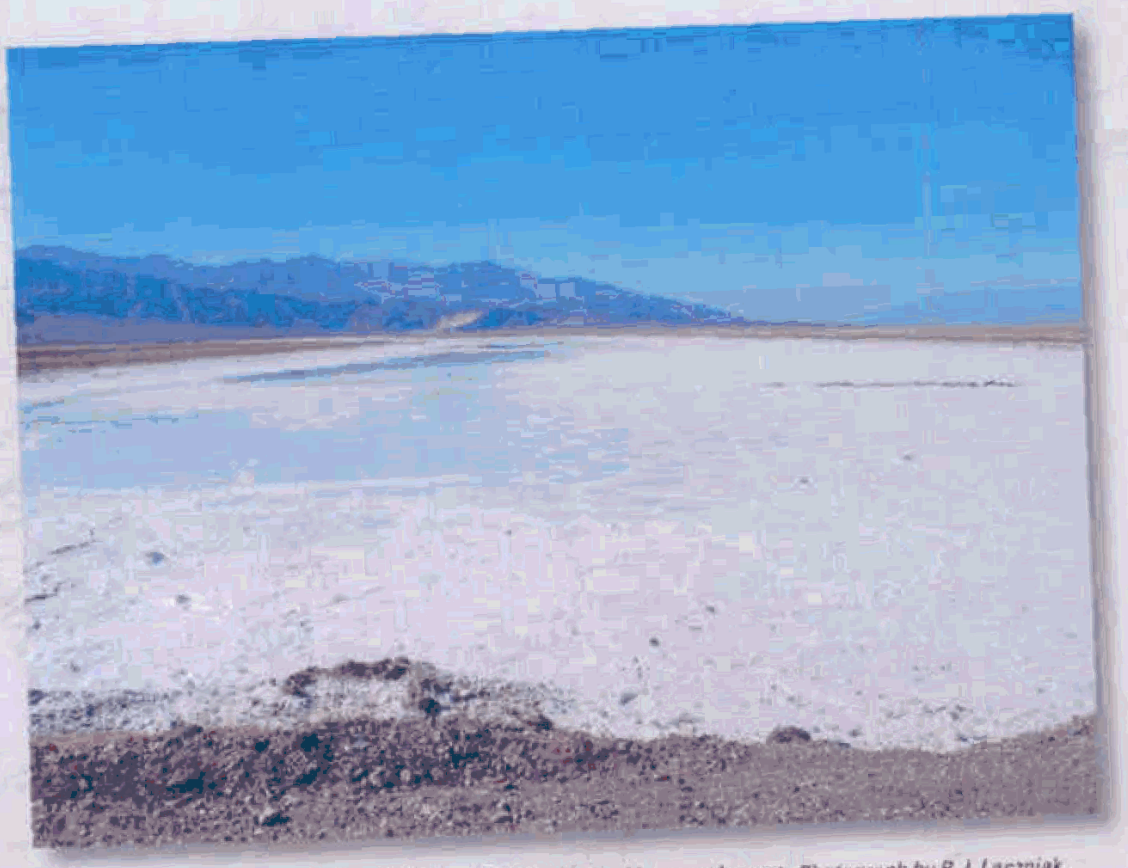

Saltpan in Badwater Basin, Death Valley, Calfornia, looking northwest. Phatograph by fiJ. Lacziak. 